\title{
TOWARDS A MINIMUM CONCEPTUALISATION OF ETHICAL ORGANISATIONAL CHANGE: THE PLATFORM PROVIDED BY THE “KING II" REPORT
}

\author{
CL VAN TONDER \\ clvt@eb.rau.ac.za \\ Department of Human Resource Management \\ University of Johannesburg
}

\begin{abstract}
Despite the fact that organisational change is one of the most frequently recurring organisational phenomena of our time, organisations do not succeed at instituting change processes effectively and dismal change "success rates" are recorded. Van Tonder and Van Vuuren (2004) suggested that the adoption of an ethical framework would significantly mitigate the implicit risk of change practices and reduce the negative consequences of such change initiatives. The literature on ethical change practices however is exceedingly sparse and offers little guidance to management on how to conduct change practices ethically. This study argues that the King II report on corporate governance indirectly yet substantially informs issues of governance, risk and ethics in change management and provides a useful point of departure for establishing ethical change practices.
\end{abstract}

Key words

Change, change management, ethical change

One of the most frequently noted truisms of our time is the increasing prevalence of turbulence in the operating context of organisations, brought on mainly by the emerging phenomenon of globalisation. The latter, in turn, is an artefact of many factors including rapid technological advances in the domains of information management and communications, and increasing access to air travel across the globe. Equally common, is the observation that the pace of change is accelerating and that change itself is intensifying. In addition to these perspectives, it was recently argued that these global circumstances are creating a "new" complex dynamic from which new types of change are emerging and which often result in catastrophic consequences (cf. Van Tonder, 2005a; 2006, on the notion of nonlinear change). Examples of this phenomenon include the demise of Enron, Barings Bank, Parmalat (International), WorldCom, and in South Africa Saambou Bank. Examples abound but understandably only the higher profile cases are reported in the business literature. Apart from these examples of organisational demise there is a substantial literature base reporting on the poor success rate of major adaptive change initiatives by organisations, with the general view taken that between $65 \%$ and $75 \%$ of these initiatives ultimately fail (cf. Applebaum \& Wohl, 2000; Beer \& Nohria, 2000; Mariotti, 1998; Mourier \& Smith, 2001; Smith, 2002; Van Tonder, 2005b). The latter includes mergers and acquisitions, downsizings, restructurings, business process re-engineering, strategic change, cultural change, continuous improvement initiatives, TQM - effectively any major change. Although the notion of change "success" and change "failure" are not yet anchored in universally acceptable definitions, it most commonly refers to the non-achievement of the initial (pre-change) financial objectives to be achieved by the change initiative. However, apart from the non-achievement of these financial objectives, major change initiatives have a significant community and societal impact - its social ramifications are massive yet are not fully accounted for before, during and after major change initiatives (Van Tonder, 2005b). For this reason it is concluded that major change initiatives, by any measure, generally do not appear to meet expectations. It is obvious that organisations still grapple with change at a time when accumulated wisdom from research and business experience should render this less of a challenge.

Furthermore, reflecting on the sudden demise of large corporate institutions, it is understandable that the issue of corporate governance will emerge as a prominent management concern as, clearly, shareholders and the main stakeholders of these institutions were significantly worse off as a consequence of these corporate failures. In these instances the type of change (however defined) that culminated in the failure or demise of the organisation embodied significant yet undetected or unmanaged risk. From this perspective it has to be argued that the issue of risk management, which is central to corporate governance, clearly cannot be defined in terms of financial risk or exposure only. Instead, a systemic perspective is necessitated in order to extend concepts of risk and risk management in particular to change management practices. As these examples suggest, shareholders and other stakeholders are continuously confronted with "risk" with regard to their "interests" - given the prevalence of change on the one hand and the "inability" of corporate office bearers to manage major change initiatives on the other.

Major change and its consequences, however, are not seen as risk areas by management, largely because of the fact that the impact and ramifications of change are not adequately measured (Burns, 2003) and consequently the damage inflicted by less than optimal change initiatives are not adequately accounted for in financial audits, financial statements and the balance sheet. In particular, it should be noted that the unavoidable and unanticipated consequences of change (Armenakis \& Bedeian, 1999) typically reside in non-quantifiable and often tacit areas. These only show up over time in indices such as general staff turnover, an unacceptably high number of bright and top achievers leaving the company prematurely, difficulty with the recruitment of appropriate staff, loss of competitiveness, a drift in focus and a commensurate shift away from the quantity, quality and time dimensions of organisational output. Less obvious are the ramifications of change that impact on employee and institutional health and well-being. Indeed, employees' experience of change appears to account for a significant proportion of their stress and stress-related illness (Briggins, 1997; Kets de Vries, 1989; Worrall \& Cooper, 1995; Worrall, Cooper \& Campbell-Jamison, 2000). Some 15 years ago Smith (1995) observed that the cost of organisational change has been widely acknowledged as being exceedingly high. Since then little seems to have changed. In this regard Van Tonder (2005b), referring to research that indicates that institutional transformation resulted in millions of lost employment opportunities and adversely affected large numbers of employees, concluded that the social cost of institutional change and transformation initiatives is staggering.

If not attended to, these largely unobtrusive consequences may eventually lead to the demise, bankruptcy or takeover of the institution or, at best, the implementation of major and drastic change initiatives to turn the institution around. Moreover, in 
the tightly integrated South African work and social contexts, major change initiatives such as these contain substantial potential for social upheaval that could damage managementlabour relations and the organisational culture in permanent ways. For the fact that the consequences of change are pervasive, tacit and only surface over extended periods of time, the domain of change and change management have not yet penetrated managerial awareness as an area of significant risk. It will be argued here that this is a dangerous oversight which is not in the interest of the institution, in particular its shareholders and notably its other key or relevant stakeholders.

The focus of this study moreover proceeds from the platform of an exceptionally underdeveloped literature base on the ethics of change and change management. The majority of scholarly contributions, understandably, direct attention to ethics and corporate governance, business ethics, ethical decision making and ethical leadership. When authors broach the subject of ethics in relation to organisational change, it becomes clear that little real attention has been devoted to the issue of ethics in change (Nielsen, Nykodym \& Brown, 1991; McKay, 2000). This holds true also for specific forms of change such as total quality management (Svensson \& Wood, 2005; Vinten, 1998), reform (Enderle, 2001), culture change, change management and the ethical consequences of these for employees (Woodall, 1996). Notwithstanding these views some attention has been directed at the ethics and change for example the ethical challenges of downsizing (Miller, 1998) and managerial views of the ethicality of downsizing (Lämsä, 1999), but these contributions remain underdeveloped.

An area that has received more attention is that which deals with employees' perceptions of "justice" during change (Cobb, Wooten, \& Folger, 1995; Shapiro \& Kirkman, 1999; Skarlicki \& Folger, 1997; Stephens \& Cobb, 1999; Wooten \& White, 1999) and resentment-based resistance to change (Folger \& Skarlicki, 1999). These studies provide some perspective on specific ethical dimensions concerned with the outcomes of the change (distributive justice), the change process (procedural justice) and the quality of interaction with the employee during the change (interactional justice). Unfortunately these studies are so narrowly focussed that the notion of an ethical change is beyond the objectives and scope of these studies. More general philosophical considerations of the ethics of change occasionally also surface, with a case in point being Calabrese (2003) who argues that change in its entirety is an ethical issue and that the decision to change or not is ethically significant. While these examples are illustrative of the few studies that sporadically surfaced over the past four decades or so, a systematic and focused attempt at articulating ethical change or stated differently, a comprehensive and coherent ethic of change is yet to surface.

Given the paucity of contributions on the ethics of organisational change, the study concerns itself with the question of what a minimum conceptualisation of an ethical approach to change and change management would be? It is in this regard that the study aims to formulate a minimalist conceptualisation of "ethical change" by contextualising the general governance and risk management principles outlined by the King II report on corporate governance (IoD, 2002). This should provide an initial platform from which to systematically pursue an "ethic of change", be this empirical exploration or further theoretical conceptualisation. At the same time it could provide preliminary parameters for managers and change agents who have to direct and manage change initiatives at the level of practice.

The emphasis accorded to the King II report follows from its wide acceptance as a national benchmark for corporate governance within the South African institutional framework, though this has since extended beyond South Africa to other states on the continent (Rossouw, 2005). Even though it is not compulsory and it is not the intention to pursue statutory status, the King II report is likely to become a statutory requirement if institutions do not sufficiently subscribe to its philosophy and principles within the provided timeframe. This further underscores its legitimacy and significance as criterion from which to extract an initial ethic of change. The report is explicit in its articulation of corporate governance and the scope of its application within organisational settings. Although not specifically indicated, change management practices are comfortably located ("interpreted") under what the King II report refers to as "functional processes" but, as argued here, it should in particular be seen as residing under "risk areas". If the validity of this simplistic logic is recognised, it then follows that organisational change practices or "change management" as it is commonly known, are therefore equally subject to the governance premises and principles of the King II report. The study then employs the King II report as the "lens" through which change practices are described. In effect it extends the report's principles to the domain of change management and reifies these in change-specific terminology. It could also be viewed as a template with which structure for a minimum conceptualisation of ethical change (or an "ethic of change") is injected into change practices. As there are clearly many different templates that can be employed (cf. Van Tonder \& Van Vuuren, 2004) the perspective introduced here serves as an initial position marker which should evolve over time in concert with a commensurate expansion of the knowledge base on change ethics.

The King II report has clearly and systematically articulated the importance, need for, and nature of corporate governance and emphasised the centrality of risk and risk management in this regard. It furthermore argued that corporate governance can only be effective if an inclusive stakeholder approach, structured around a clear set of corporate ethics, is pursued. The study follows this structure and briefly reflects on the notions of corporate governance, risk and ethics as embodied in the King II report and continuously transfers and translates these principles into relevant change practice principles. It leads with corporate governance, which is principally concerned with the overarching objective of directing and controlling the organisation. This is followed with brief attention to the issues of risk and its management as well as governance in respect of ethics.

Corporate Governance and a minimalist "ethic of change" As an introduction to the King II report, Cadbury's view of corporate governance is quoted as... "Corporate governance is concerned with holding the balance between economic and social goals and between individual and communal goals ... the aim is to align as nearly as possible the interests of individuals, corporations and society" (IoD, 2002, p.7).

The issue of corporate governance was propelled into prominence by institutional decision making that appeared to favour a select few or some stakeholder constituencies, with inadequate attention to the interests of other and all significant stakeholders and in many instances at the cost of the interest of these stakeholder constituencies. High profile examples of corporate failure and demise (more specifically abuse and fraud) have led to greater awareness of the inadequacies of governance (Vinten, 2001) and have prompted unparalleled public concern about ethics and integrity in business (Fulmer, 2004). Corporate behaviour of this kind reveals the implicit risk that has not been managed adequately by these institutions and which is the subject of governance practices.

Bearing the above articulation of corporate governance in mind and reflecting on the undesirable social consequences of the vast majority of major change initiatives, it is evident that the "balance" to which Cadbury refers, is nonexistent... that major change decisions are effectively dominated by shareholders' interests. The latter, it seems, in many instances are not served well either, with the number and impact of corporate failures 
clearly negating shareholders' interests. Dramatic corporate failures are not the only evidence of shareholders interests not receiving their "fair share" of attention. In this regard a KPMG worldwide survey on mergers and acquisitions revealed that only $17 \%$ of these profoundly disruptive change initiatives actually create shareholder value or, conversely, that $83 \%$ do not add value (Hattingh, 2004). In a similar vein Miller (2004) indicated that $70 \%$ of change projects fail to secure the anticipated benefits. If we subscribe to Cadbury's (and hence the IoD's) view of corporate governance then clearly organisational change practice in general reveals an absence of corporate governance. At the same time recognise that change practices create unusual opportunities for the abuse of power and the manipulation of information (Mayon-White, 1994) largely because of the vulnerability of employees (individuals and groups) - a perspective that implicitly argues for a pronounced presence of corporate governance in change.

The IoD's (i.e. Cadbury's) articulation of corporate governance (above) pertinently highlights a focus on stakeholders and in particular the interrelationships between stakeholders as a central point of departure. In this regard stakeholder theory has much to offer. Drawing on Freeman (1984) and Rossouw and Van Vuuren (2004), stakeholders can be viewed as those individuals or groups with an interest in the organisation (or elements of it) and who are capable of influencing it, or are themselves impacted on by the organisation. Stakeholder theory (cf. Haberberg \& Rieple 2001) essentially argues that organisations have stakeholder groups that influence the functioning of these organisations, as well as stakeholders on whom the organisation have an impact. Secondly, the general interaction between stakeholder groups and organisations have an influence on specific, more prominent stakeholders, which, in turn impact on the organisation and, thirdly, the perspectives of prominent stakeholders impact on the feasibility of the organisation's strategic options. This view that stakeholder theory offers a means of identifying and reconciling disparate stakeholder interests within more effective and ethical corporate governance (Simmons, 2004, p. 603) therefore appears to be quite appropriate and meshes with the emphasis accorded to stakeholders in the IoD's articulation of corporate governance. Moreover, research evidence suggests that decision making is enhanced by incorporating stakeholder perspectives, in particular in stakeholder-accountable organisations (e.g. Pettijohn, Parker, Pettijohn \& Kent, 2001). Such an emphasis on a stakeholder approach is consequently highly appropriate for South African and African settings. Proceeding from the perspective of the King II report, and through logical extension, we will argue that organisational change practices that are engaged from within a sound corporate governance framework consequently will acknowledge and incorporate all those relevant stakeholders impacted on by the change.

In the second instance, organisational change practices will reflect a balanced i.e. an equal consideration of the interests of each of the identified (relevant) stakeholder constituencies. In this regard the King II report (clause 5.1, p.7) argues for the "modern approach" according to which a Board will identify the company's stakeholders, including its shareholders, and will then agree on the nature and content of policies that relate to the relationship with these stakeholders and how these relationships should be advanced and managed in the interest of the company. In clause 5.3 (p.8) this approach is referred to as the "inclusive approach" as it allows for the incorporation and consideration of at least the community in which the company operates, its customers, its employees, and its suppliers - as key stakeholder constituencies that will impact on the performance of the company. Extending this to a change setting, it now becomes possible to retroactively evaluate the extent to which a specific change decision or series or change decisions have embodied due consideration in equal proportion, of the interests of the various stakeholder constituencies as, after all, the report argues that the relationship between the institution/company and its stakeholders should be mutually beneficial (refer clause 6. p.8).

A business artefact of such an inclusive perspective, which recognises the interdependence of the company/organisation and its operating context, is the move towards "triple bottom line" reporting and accounting (IoD, 2002, pp.10-11). This form of reporting constitutes a more embracing perspective that focuses not only on the financial, but in particular also on the economic, environmental and social dimensions of an organisation's activities. Economic activities include the traditional financial considerations but also non-financial aspects relevant to the institution's business, whereas environmental aspects are concerned with the effect of the institution's products or services on the environment, and social aspects relate to ("embrace" refer clause 17.1, p.11 of the King II report) values, ethics and reciprocal relationships with stakeholders other than the shareholders. Again, through logical extension, change practices and change activities of an organisation should similarly be subjected to a multidimensional concept of change reporting and accounting. This perspective meshes with the (neglected) view that the causes of failed organisational change are multifaceted and complex beyond the common perception prevailing in the practitioner-dominated literature on change management (Van Tonder, 2004a; 2004b; 2004c). Indeed, one of the problems undergirding the poor track record of organisational change initiatives is the inadequate definition of change success that is typically formulated for a change initiative (if at all). In those rare circumstances where this is consciously addressed, it generally tends to focus on the minimisation of costs and / or the maximisation of profits i.e. the financial wellbeing of the institution. The fallacy of this approach is exposed by research that reports on the dramatic social consequences of organisational change (cf. Cameron, 1994; Hattingh, 2004; McGreevy, 2003; Offerman \& Gowing, 1990; Skrzycki, 1989), change-related stress (for example Cartwright \& Cooper, 1993; Panchal \& Cartwright, 2001), psychological shock (Johnson, Hoskisson \& Hitt, 1990), the traumatic side effects of change (Coates, 1998), and generally the significant direct and indirect costs associated with change (Morrell, Loan-Clark, \& Wilkinson, 2004). These pervasive and predominantly "non-financial" consequences have a significant indirect cost that with time inevitably converts into and manifests as direct financial costs. The latter in turn determines the success or otherwise of the change initiative. It is noteworthy that change initiatives may appear to be successful in the short term but once an extended timeframe is adopted, turn out to be unsuccessful (Beer \& Eisenstat, 1996). While it is not possible to gauge how pervasive this phenomenon of short-term "success" - medium term failure is, questions on the probability of this dynamic suggest concern in this regard (Armenakis \& Bedeian, 1999). At a managerial level this dilemma is seldom detected or recognised simply as "...no one gathers statistics on how successful organisations are at managing change" (Burnes, 2003, p.629).

It is noteworthy and certainly no coincidence that near perfect alignment is observed between the notion of "successful change" with its emphasis on the participation and involvement of employees and other stakeholders (cf. Van Tonder, 2004a), and the characteristics of good corporate governance as propagated by the King II report and, specifically, its argument for adopting an inclusive stakeholder approach that is demonstrable and measurable in the triple bottom line reporting and accounting process. Extrapolating from this platform of an inclusive stakeholder approach, an "ethic of change" would then include, as a minimum, a definition of change success that extends substantially beyond the financial outcomes of the initiative, to also embrace non-financial, social and communal change outcomes (Van Tonder, 2004a). It is however highly improbable that the adoption of such a multidimensional concept of change and change success will bear fruit in the absence of an institutionalised change measurement philosophy. 
TABLE 1

GOOD CORPORATE GOVERNANCE CHARACTERISTICS: APPLICATION TO CHANGE PRACTICES

\author{
Characteristics of Guiding parameters extracted and translated \\ good corporate for change processes and practices
}

governance $^{1}$

1. Corporate

discipline

- How aware and committed is the organisation (e.g. senior management) to systemic application of the principles of good governance for example in change initiatives and management?

- How committed are senior management, line managers and change agents to adhere to change practices that are universally recognised as correct and proper?

2. Transparency - How easy is it for any stakeholder or outsider to gain access to, and engage in meaningful analysis of the institution's sanctioned change decisions, actions and practices prior to and during change initiatives?

- How quickly is the data provided? How truthful and accurate is the provided change data?

3. Independence - Are sanctioned mechanisms in place that will detect and minimise or avoid potential conflicts of interest during the different stages of the change process?

- Is the change management team, the change decision making body, the consultative forum, the research group/ team and other collective task entities balanced in their composition i.e. representative of all the relevant stakeholders?

- To what extent do the change policies and procedures safeguard and balance the interests of any and all the stakeholder constituencies' interests at all times and in all forums?

- How objective are the change processes and decisions arrived at?

4. Accountability - To what extent are those mandated and tasked with responsibilities of introducing and implementing change initiatives held accountable for their decisions and actions, and the outcomes of these decisions and actions?

- How clear is the hierarchical line of accountability for change initiatives and practices?

- How committed is the senior management to accountability for change initiatives and their outcomes?

- Are effective mechanisms in place that will enable clear accountability and effective management in terms of accountability?

5. Responsibility - Are those tasked with change initiatives acting responsibly towards all stakeholders of the organisation and hence the change process?

- What are the quality and availability of evidence, on the basis of which responsible action prior to and during the change process can be ascertained?

- How effective and efficient are the systems, mechanisms and procedures that have to detect deviation from acceptable change practices, enable corrective change practices and penalise mismanagement of change initiatives?

6. Fairness

- To what extent are the rights of various groups (stakeholders) acknowledged, respected and protected during the entire cycle of the change process?

- Is equal consideration given to the interests of the different stakeholders (including minority stakeholders)?

- Do the benefits and burdens of change decisions accrue equally to each and all stakeholders?

- To what extent do change management systems, policies, practices and procedures entrench fairness to all stakeholders?

7. Social - How aware and responsive is the organisation to responsibility the social issues, consequences and implications of change initiatives?

- To what extent do change initiatives reflect a high priority on, and commitment to ethical standards and conduct prior to, during and on completion of the change initiative?

- To what extent are change decisions, practices and the entire process perceived by stakeholders as non-discriminatory, non-exploitative and responsible to environmental and human rights issues (clause 18.7. p.12).
The King II report (IoD, 2002, pp. 11-12) proceeds to circumscribe the notion of good corporate governance and articulate seven characteristics which are directly transferable to change practices within organisations. These are corporate discipline, transparency, independence, accountability, respon-sibility, fairness, and social responsibility. Of these, fairness, accountability, responsibility and transparency are widely subscribed to and have become known as the "cardinal values" of good governance (Rossouw \& Van Vuuren, 2004). These values are applied to an organisational change setting and further reified in Table 1 .

An "ethic of change" premised on the generally prescribed parameters of corporate governance as per the King II report will therefore be compliant with and reflect:

- an inclusive stakeholder approach that consciously incorporates and considers the interests of at least the employees, customers, and suppliers affected by the change process, and the community within which the change process is bound to have an impact.

- a balanced consideration of all stakeholder interests at all stages of the change initiative or process,

- change success defined in terms of multiple outcome dimensions including financial, social, and communal, and supported by an institutional (change) measurement philosophy.

- the cardinal values of good governance as a minimum, but preferably the seven attributes or values that characterise good corporate governance.

Risk management and a minimalist "ethic of change"

The case has been argued for framing organisational change practices and the decisions to engage in these practices as major areas of "risk" for the institution and is consequently not restated. Note however that the notion of risk management is clearly entrenched as a critical parameter of corporate governance, in particular the careful and considered engagement of risk in exchange for corporate rewards (IoD, 2002, p.73) and is defined as the identification and evaluation of potential risk areas as they pertain to the organisation, as well as the process to remove or minimise the risk. In this regard the King II report also stipulates that the risk management process entails the planning, arranging and controlling of activities and resources to minimize the impact of risk and, in this instance, internal control measures constitute a central consideration. The King II report and in particular section two deals at length with the notion of risk and risk management - a framework which equally and fully applies to the domain of organisational change practices. Again, in view of the limited awareness of the tacit and less obvious consequences of major change initiatives, it would be safe to conclude that the prescribed parameters for dealing with risk are unlikely to be observed in the vast majority of change practices in which organisations engage on a daily basis.

In an institutional context the risk framework provided by the King II report becomes an important instrument with which to approach any major change decision. Note for example that risk management, which is seen as an operational function and responsibility, relies substantially on effective and continuous monitoring of the risk in the various functions and portfolios of the organisation. Continuing from this premise, if follows that once organisational change practices are recognised as areas of risk, that change practices, apart from defining and viewing organisational change practices as potential areas of risk, need to be subjected to an effective and continuous risk monitoring process and mechanisms prior to, during and upon completion of change initiatives (from conception to conclusion of the change initiative). 
The cited examples of sudden and dramatic corporate failure while reflective of dramatically changing operating conditions, in particular reveal not only the absence of a risk management mindset, but provide exemplary evidence of inadequate or "failed" monitoring systems. Van Tonder $(2005 a, 2004 c)$ for example highlighted the critical managerial deficiency in areas such as managerial sensitivity, and capabilities for detecting the developing catastrophe that eventually led to the "run-ondeposits" at Saambou Bank and soon after resulted in the irreversible collapse of the institution with significant losses ("damage") incurred to each of the stakeholder constituencies. From this perspective it can be postulated that organisational change practices that embody "good governance" will entrench a risk management approach which is evidenced in a clear system of internal control that ensures risk containment and management in change practices.

The recommendation that companies should develop a system of risk management and internal control that incorporates, inter alia, a demonstrable system of dynamic risk identification, and a commitment by management to this process (IoD, 2002, p.81) clearly does not apply to the financial domain only, but to the organisation in its entirety and consequently also to the domain of human resources and change management practices. In this regard the King II report argues for a continuous and systematic assessment of risk. It is interesting to note that the report singles out specific circumstances that require close attention from a risk assessment perspective which, without exception, articulate some form of institutional change e.g. "...substantive changes to the operating environment, new personnel, new or revamped information systems, rapid growth, new technology, new products or activities, corporate restructuring, acquisitions and disposals, and changes in foreign operations." (IoD, 2002, p. 78).

Again, proceeding from the risk management parameters highlighted in section two of the King II report, guiding parameters for change practices are extracted and presented in Table 2. These parameters are neither a complete nor necessarily a minimum application of risk management considerations to change management (initiatives and practices). It does however convey a sense of the importance and seriousness of risk and its management in an organisational sense, and suggests the substantive nature of work that would be needed to reduce the implicit risk in a change initiative once it is formally recognised as an area of risk.

Non-attendance to risk in general signifies a careless and irresponsible denial of the interests of those who may be impacted on by the risk. In an organisational sense nonattendance to risk will materially and adversely impact on the interests of key and relevant stakeholders. Such action, when considered against a view of business ethics as the identification and implementation of standards of conduct that will ensure (as a minimum) that stakeholders' interests will not be detrimentally impacted on, but preferably enhanced (Rossouw \& Van Vuuren, 2004) is therefore fundamentally

TABLE 2

Risk MANAgement PARAMETERS APPLIED TO CHANGE PRACTICES

Application of risk management parameters 2 to change practices

From Chapter 1

- Are adequate plans, budgets, monitoring and controlling mechanisms in respect of a given change initiative, established prior to initiating the change?

- Have the potential risks embodied in the change initiative been identified and analysed?

- Has the impact of change risk(s) on all stakeholder constituencies been considered fully and responsibly?

- Are internal control mechanisms established for the decision, design, and implementation of any given change initiative/process?

- Do these internal control measures provide a reasonable assurance that the stated change objectives and therefore outcomes, which have been formulated in accordance with the agreed definition of change success for the initiative, will be achieved? More specifically, do these internal control measures provide a reasonable assurance that

- the change initiative will itself be executed effectively and efficiently?

- the change initiative, once concluded, will improve the effectiveness and efficiency of operational processes (organisational functioning in general)?

- The organisation's assets such as capital, people, information, reputation and market perception, and brand value will be safeguarded?

- The change initiative will comply with applicable laws, regulations and supervisory requirements?

- The change initiative, once concluded, will support business sustainability regardless of the operating conditions?

- $\quad$ Reporting on the change initiative will be reliable?, and

- Conduct towards all stakeholders prior to, during and on completion of the change initiative will be responsible?

- Do all functionaries involved in the research, planning and execution of the change initiative acknowledge that the identification and management of risk implicit in the change initiative, is the responsibility of each and every functionary?

- Are control measures to manage change risks

- Effective?

- Formally reviewed on a regular basis?

From Chapter 2

- Is clear management accountability established for risk management in terms of the design, implementation and monitoring of change initiatives?

- Is a systematic and documented assessment of the risk management approach, processes, activities and mechanisms in terms of change initiatives undertaken on at least an annual basis?

- Does the assessment adequately circumscribe the organisation's exposure to physical, operational, human resource, financial and credit, market, technology, compliance and business continuity risks during change initiatives?

- Is the organisation's position on the risks that are implicit in change initiatives, incorporated in its public statement on risk management?

From Chapter 3

- Are the control mechanisms to manage the risk in change practices a coherent part of the overall organisational "control environment" i.e. do they align with and complement the organisation's ethical values, management style, culture, and so forth....

- Are change management practices for example guided by a written code of conduct, training programmes in respect of corporate governance, risk, corporate and ethical values; clear authorisation protocols and performance management premised on specific, clear performance indicators?

- Is pertinent information arising from an assessment of the inherent risks in change initiatives/practices timely identified, captured and communicated - in such a manner that preventative and/or corrective action to minimise and manage the risk, is timely instituted?

- Is an effective information management system in place to enable measurement of change progress and results against stated change objectives?

- Is the monitoring of risk in change initiatives and practices undertaken on a continuous basis? Has the company's system of risk management and internal control been operationalised specifically for change initiatives and practices? More specifically, does this system demonstrate/convey:

- Documented internal control and risk management measures and procedures?

- Dynamic identification of change risk?

- Management commitment to the system and consequently to the management of risk in change initiatives?

- A coherent series of activities that will mitigate the change risk(s)?

- Systematically documented communication of change risks?

- Systematic documentation of the costs of non-compliance and losses - if change practices were not approached and managed as risk?

- Key risks (documented) that are most likely to present during major change initiatives and that could affect the interests of shareholders and other relevant stakeholders? 
and undeniably unethical. Attending to risk in change is therefore an imperative if change practices are to be deemed "ethical" at all. In a general sense, an ethic of change will by necessity reflect a considered, responsible, and adequate treatment (and engagement) of risk.

Reflecting on the application parameters extracted from the King II report and presented in Table 2, it has to be concluded that an ethic of change from a risk management perspective will

- entail a more encompassing and inclusive approach to analysing, interrogating and planning change initiatives and practices, than has been the case to date,

- be characterised by a comprehensive, transparent and effective system of internal control, identification and management of the risk implicit in change initiatives and practices,

- systematically articulate "change risks",

- establish the cost of non-attendance to the change risks,

- consistently report (communicate) such risks and their analyses,

- move to eliminate, minimise or contain risks,

- ensure clear accountability for the management of change initiatives/practices and hence change risks

- continuously and effectively assess and monitor change initiatives, processes and practices for risk

As change is not yet adequately recognised as an area of significant corporate risk, change practices and "change management" are bound to display significant deficiencies when benchmarked against the risk management parameters indicated above and in Table 2. Compliance with these requirements poses significant challenges to institutional office bearers and some of the implications that arise from such a change risk perspective for example entail:

- An adequate conceptualisation of "change success" (objectives articulated as outcomes) for any given change initiative that incorporates the interests of all relevant stakeholders.

- The adoption and institutionalisation of a change measurement philosophy and fairly continuous change measurement practices with its requisite demands in terms of instruments and rigour.

- Creating a capability for measuring and quantifying the initial indirect and non-financial impact of major change initiatives - to the extent that valid and defensible cost-benefit analyses can be performed and the likely influence this will exercise on overall business objectives and business sustainability can be gauged.

- Clear accountability parameters for "change success" (intermediate and final outcomes).

- Focused and dedicated performance management with regard to any given change initiative or practice, premised on specific indicators of change performance.

While the institutional challenges that accompany a corporate governance and risk management perspective on organisational change practices are substantial, arguments in section 2 of the King II report intimates at the potential contribution of a corporate ethics philosophy. The view that ethics could substantially ameliorate change practices (by reducing change "risk") was firmly stated by Van Tonder and Van Vuuren (2004). In this study it is argued that the elimination or reduction of change risk e.g. through the institutionalisation of corporate governance and risk management philosophies and practices, may be expedited by commencing with a corporate ethics approach and gradually building up towards an adequate risk management and corporate governance model. The logic of this view is premised on empirical evidence that indicates that most of the risk implicit in change practices is social in nature ${ }^{3}$. Section 4 of the King II report pertinently addresses the importance of an ethical approach in organisations, which is further contextualised for change practices in the ensuing section.
Corporate ethics and a minimalist "ethic of change"

Ethics can be viewed simply as the moral principles that govern behaviour (Kavanagh, 2002) or more elaborately as a system of accepted beliefs and principles of conduct typically based on moral imperatives that govern the behaviour of individuals and the groups/organisations to which they belong (Irvin, 2002). In general though, it is concerned with that which is considered good and right in human interaction- effectively the interrelationship between the three concepts "good", (the) "self" and (the) "other" and ethical behaviour, it is argued, results when one considers not only what is good for oneself, but also what is good for others (Rossouw \& Van Vuuren, 2004 p. 3). In an organisational sense an ethics perspective then would speak to the relationship between relevant stakeholders and will imply an "agreed definition" of what is in the interest of the organisation (i.e. what is "good" for the organisation) and in the interest of (i.e. "good" for) each of its relevant stakeholders.

Although the literature on the ethics of change (a "change ethic") is exceptionally sparse, scholarly contributions in this regard are beginning to surface and are bound to gain momentum once the implicit risk in major change initiatives is formally acknowledged. The limited attention thus far directed at change as focus of risk and ethics however do not detract from the reality that change practices are characterised by significant ethical considerations. Calabrese (2003, p.9) in fact argues that "The whole notion of change is an ethical issue."

Section 4, chapter 3 (pp. 101-106) of the King II report (Ethical Practices and Organisational Integrity) addresses the issue of corporate ethics and is fairly explicit in its coverage of the subject. It outlines a definition of a company's ethics (clause 1), the role and purpose of such ethics (clauses 2 to 6), core ethical principles (clause 7), structural measures to support ethical business practices (clause 8), implementation and monitoring of ethics programmes (clauses 9 to 10), the responsibilities of various functionaries with regard to ethical corporate conduct (clause 11), compliance with legislation and guidelines to combat unethical conduct (clauses 12 to 16 ).

Contextualising King's ethics principles and recommendations for the domain of change management is of course justified from the perspective that the report argues that ethics applies to the organisation's activities, internal relations and interactions with external stakeholders, and do not further differentiate between different functional disciplines, departments or sections within the organisation. From this perspective the decision to engage in major change (for example a merger or strategic alliance) and the subsequent planning and implementation of this initiative are therefore unavoidably subject to the company's ethics approach and policy and has to be guided by its (established) ethical principles, norms and standards. The perspective presented in clause 3 for example argues that all the organisation's business goals, policies and activities are subject to the company's ethical programme and principles and again clearly mandates that all change initiatives be subjected to the same ethical programme and principles. It is therefore redundant but necessary to posit that good governance in change practices will incorporate and reflect compliance with the company's ethical programme, principles, norms and standards. Working on the assumption of legitimate transferability argued above, a selection of some of the more central concerns that are useful also in articulating change ethics, is presented in Table 3.

Note in particular that the King II report states that the meaningfulness of a company's ethical principles is derived from the involvement of its various stakeholder constituencies (refer also earlier comments on stakeholder theory). Stakeholder 
representatives, accordingly, should be actively involved in the process of identifying and circumscribing the ethical principles and standards that will guide organisational practices. Following the logic of this study, this principle applies equally also to ethics pertaining to organisational change practices. Apart from being prominently argued in the King II report, the adoption of an inclusive stakeholder approach enjoys wide acceptance and is regularly addressed in the literature (Pettijohn, Parker, Pettijohn \& Kent, 2001; Simmons, 2004).

TABLE 3

KING'S "ETHICAL PRACTICES" APPLIED TO ORGANISATIONAL CHANGE PRACTICES

King II Report Application to organisational change practices

Section 4

Chapter 3

Clause 1:

Definition of a

company's ethics

- Are change practices, internal relations that are affected by the change and interactions with external stakeholders who are impacted on by a change initiative conducted and managed in accordance with clear ethical principles, norms and standards?

- Are clearly defined standards of behaviour for all change decisions and actions formulated and regularly reviewed?

- To what extent do employees responsible for the change and relevant stakeholders (e.g. employee representatives, consultants) adhere to these defined standards of conduct?

Clause 3 - Do established principles and standards of ethical conduct for change initiatives (processes) and practices exist?

- Do organisational change practices convey demonstrable adherence to these principles of ethical conduct?

Clause 4 - Have all relevant stakeholder constituencies participated in and therefore informed the ethical principles and standards that guide the organisation's change practices?

- Do these ethical principles and standards for change practices clearly articulate behaviour and accountability with regard to:

- responsibilities to shareholders and the financial community

- relations with customers and supplier

- employment practices

- the community and broader social environment

- Are these stakeholder constituencies engaged on a continuous basis to review/assess the relevance and appropriateness of ethical principles and standards for change practices?

Clause 5 - Have the ethical principles and standards developed for change practices been captured in a code that is easy to communicate?

Clause 6: Code - Does the code of ethical change practices

of ethics - take its cue from the corporate ethical standards

- inform and guide change policy and practices?

- clarify what is considered acceptable and unacceptable change practices?

- guide ethical behaviour of all officials and functionaries that are involved at the different evels of the change initiatives?

- provide clear guidance with regard to difficult change decisions?

- facilitate the identification of ethical entrenchments within the change initiative and change practices?

- promote awareness of and a sensitivity to ethical issues, notes and considerations prior to, during and on completion of a change initiative?

- facilitate the resolution of conflicts and disagreements encountered during the course of the change initiative?

- articulate the scope and parameters of the organisation's social responsibility when it comes to change initiatives, processes and practices?

- clearly articulate and inform relations among stakeholders who are engaged and impacted on by the change process?

- further bolster and enhance the ethical reputation of the organisation as a consequence of ethical change practices?
Clause 7: Core ethical principles

- Do change initiatives and practices consistently subscribe to the principles (and values) of

- Fairness?

- Transparency?

- Honesty?

- Non-discrimination?

- Accountability and responsibility?

- Respect for human dignity, human rights and social justice?

Clause 8:

- Are structural measures introduced to embed ethical change practices?

- To what extent are these structural measures utilised in pursuit of consistently ethical change practices?

Clause 9:

- To what extent do change practices comply with established ethical principles and standards for change practices?

- Are change practices regularly monitored and evaluated for compliance with these principles and standards?

Clause 10:

- Are reporting on ethical conduct and compliance during change processes regular and adequate e.g. are regular interim reports on ethical conduct submitted during the implementation of a change initiative/ programme?

Clause 11: - Are the ethical roles, responsibilities and accountabilities of directors, management, employees, suppliers, consultants and contractors during change initiatives and practices clearly articulated and differentiated?

- To what extent do the various functionaries comply with these ethical roles, responsibilities and accountabilities? Are the consequences of noncompliance clearly communicated and understood by all functionaries?

- To what extent are the various functionaries held accountable for their conduct in terms of the stipulated ethical roles, responsibilities, and accountabilities?

Clause 12:

- Do change practices and initiatives comply with prevailing legislation that have a bearing on them?

Clause 13:

- Do the various functionaries understand that their role is also to actively combat unethical conduct during change initiatives and have a responsibility to uncover and report on unethical change practices?

It has to be concluded that if a corporate ethics perspective as per King II is adopted, an "ethic of change" can be defined substantially. This is clearly evidenced in Table 3. In essence an adequate (minimum) "ethic of change" would have to:

- Clearly articulate those change positions, practices and outcomes that are in the interest of the organisation and its relevant stakeholders

- Engage stakeholders in a collective and inclusive approach to deliberate on change considerations at all stages of the change initiative,

- Establish an "ethics code" together with appropriate policies for change practices that clearly stipulate behavioura principles, standards of conduct, as well as explicit roles, responsibilities and accountabilities for each participant and functionary prior to, during, and on conclusion of the change initiative.

- Monitor, report on, and ensure compliance with ethical principles and standards of conduct on a consistent basis.

To be expected, the King II report clearly articulates the responsibility parameters of the board of directors, management, employees, suppliers, consultants and contractors with regard to the organisation's ethical conduct. It recognises that no employee, office bearer or other stakeholder is exempt from the task of maintaining sound ethical practices. These guidelines, again, are nondiscriminatory and apply to all regardless of their role and function within the organisation. As such these guidelines provide a clear platform from which to develop and structure the ethical responsibilities and guidelines of those office bearers who are more directly involved in change initiatives and change practices. Typically these would include the change champion(s) i.e. the senior executives and board 
directors that take charge and lead the change initiative, the relevant managers that have to implement the change decisions and practices, the various change consultants and change facilitators (regardless of whether they are external or internal) who design and facilitate the change initiative, and designated representatives from the different stakeholders constituencies who participate in the change management forum or team. Ultimately, of course, the successful introduction and sustainability of an ethically-informed change philosophy, policy and practice commences with the board of directors (or the political leadership in public sector institutions), who have to acknowledge that change processes constitute a risk area that necessitates careful corporate governance and is substantially the subject of ethics. After all, the King II report argues "... corporate governance has an ethical dimension that can be viewed as the moral obligation for directors to take care of the interests of the investors and other stakeholders" (IoD 2002, p.106).

While the IoD's perspective on the moral obligations of directors naturally extends to the domain of change management and change practices, there is unfortunately, as yet, no evidence that this is the case. Consider in this regard Garofalo's (2003) view that empirical evidence of more ethical individuals and institutions remains to be discovered. Fisher (2003) for example stated that more and more organisations are developing codes of ethics and making public commitments to ethical conduct, yet the behaviour of business leaders has not markedly improved. The author suggests that this is indicative of a "surface approach" to business ethics i.e. one that is essentially motivated by self-interest (e.g. improved image, profits etc.) and not because of a fundamental belief in and commitment to "doing the right thing" because it is the right thing to do (Calabrese, 2003; Harrison, 2001). This behaviour approximates what is referred to as "Carr's ethics bluff" whereby organisations take morally responsible decisions ultimately to improve profits or minimise losses (Carr, 1968; Jennings, Smeltzer \& Zener, 1993). Apart from the cynicism that it breeds (Gray, 1990) such approaches fail to promote ethical behaviour (Fisher, 2003). This consequently provides an important reality check on contemporary (claimed) commitment to ethical business practices. This study, through extension and reification, argued that the manner in which the philosophy, principles and recommendations have been defined and articulated in the King II report, specifically in terms of corporate governance, risk and ethical practices, speak to any and all organisational processes and functionaries. Change practices and change managers, contrary to practice, cannot escape the reach and ramifications of the King II report's recommendations. It is consequently submitted that organisations who claim to commit to the philosophy and principles of the King II report, de facto commit to the notion of ethical change. Where this is not borne out by actual practice, the institution's claimed commitment is undoubtedly suspect.

\section{CONCLUSION AND RECOMMENDATION}

Organisational change is mandated by rapidly changing operating conditions, but the risk inherent in attempts at brokering these adaptive organisational responses is the central concern. To argue however that change is risk, is not to simultaneously argue that it should be shunned... Calabrese (2003, p.9) aptly captures the essence of an ethic of change when he asks... "Why change if the change does not better the organization? Why refrain from change if the change betters the organization?" From this perspective a solid ethic of change can significantly diminish the risk.

From a different vantage point it is worth noting that change practices and in particular the "case for change" and pre-change decision making will become increasingly the subject of scrutiny and public debate. With employment creation and the shedding of structural employment opportunities (with its associated retrenchments) becoming a central focal point in organised labour's stance on national economic policy, change practices which have become a common "conduit" for such job losses, are bound to invite greater scrutiny. Indeed, the less-than-desirable performance outcomes of major change initiatives such as mergers and acquisitions, downsizings, and various strategic change initiatives are becoming more visible and are reported in the business press with greater frequency than before. Moreover, this is occurring not only in scholarly circles and board rooms, but public awareness of the "dark side" of corporate change and its associated risks is also increasing. The second contributor is the increasing dissatisfaction and impatience of shareholders with the experienced lack of "value-add" realised from major change initiatives (cf. Hattingh, 2004). With disenchantment voiced by these two major stakeholder constituencies against the prevailing "change management paradigm", organisational management may well be confronted with declining support and growing distrust if they do not materially alter their approach to large scale change. It is again suggested that ethical change (or an institutional change ethic) will provide a more meaningful and productive alternative in this regard.

To date however the notion of ethical change practices was largely neglected and hence is an underdeveloped concept, but this will change in the current competitive climate and increasingly governance-orientated institutional landscape and will become a prerequisite for survival. Moreover, historical practice and the sparse literature available on the subject do not preclude institutional office bearers from adopting and pursuing ethically based change practices. In this regard the consideration of risk management, corporate governance, and ethical conduct in the King II report (IoD 2002) provides an adequate platform and a clear starting point for defining the company's specific change philosophies, policies and practices. The adoption of a sound business ethics philosophy may be indicative of a morally good company, but it may well also prove to be a sound investment. The decision to adopt and engage in ethical business practices in the final analysis, however, should not be done on the grounds of economically-based arguments, but because it is "the right thing to do". By the same token the pursuit of ethical change practices would substantially diminish the risk inherent in these initiatives, facilitate greater cooperation, and produce outcomes that are more compliant with stakeholder expectations. While these are obviously desirable outcomes, ethical change practices, viewed from a societal and stakeholder perspective, ultimately constitute "the right thing to do".

\section{In closing}

For a substantial period of time it has been argued that the "key" to future organisational success was regular (adaptive) "change". During the past two decades or so this view has gradually changed to emphasise not so much the change per sé (change is a fait accompli) but rather "how to" change. This "how to" of change was articulated with great regularity, but not in ethics terminology, or from within an ethics framework. As a consequence of global concern with corporate governance, risk management and ethical conduct by institutions and their representatives, this "how to" of change will increasingly be elaborated in terms of ethical and unethical change practices. With this, the prospects of change performance ("success") improve substantially, yet at the same time change practices will offer a window on the morality of the organisation. Change practices will inevitably expose the organisation's sense of morality and commitment to ethics. As a result the pursuit of change now significantly raises the ante for management and human resource functionaries ... even compliance with a minimalist change ethic will prove substantially challenging and demanding. Then again, is doing the right thing in change (for the right reasons) a matter of choice? 


\section{REFERENCES}

Applebaum, S.H., \& Wohl, L. (2000). Transformation or change: Some prescriptions for health care organizations. Managing Service Quality, 10 (5), 279-298.

Armenakis, A.A., \& Bedeian, A.G. (1999). Organizational change: A review of theory and research in the 1990s. (Yearly Review of Management). Journal of Management, 25 (3), 293-313.

Beer, M., \& Eisenstat, R.A. (2000). The silent killers of strategy implementation and learning. Sloan Management Review, Summer 2000, 29-30.

Beer, M., \& Nohria, N. (2000). Cracking the code of change. Harvard Business Review, May-June, 133-141.

Briggins, A. (1997). Perform or perish. Management Review, 8 (6), 6 .

Burnes, B. (2003). Managing change and changing managers from ABC to XYZ. Journal of Management Development, 22 (7), 627-642.

Calabrese, R.L. (2003). The ethical imperative to lead change: overcoming the resistance to change. The International Journal of Educational Management, 17 (1), 7-13.

Cameron, K.S. (1994). Guest editor's note: Investigating organizational downsizing - fundamental issues, Human Resource Management, 33 (2), 183-188.

Carr, A. (1968). Is business bluffing ethical? Harvard Business Review, Jan-Feb, 43-51.

Cartwright, S., \& Cooper, C.L. (1993). The psychological impact of merger and acquisition on the individual: A study of building society managers. Human Relations, 46 (3), 327-347.

Coates, N.R. (1998). The psychological adjustment of middle managers after revolutionary organisational change. Unpublished Master's dissertation, Rhodes University, Grahamstown.

Cobb, A.T., Wooten, K., \& Folger, R. (1995). Justice in the making: Toward understanding the theory and practice of justice in organizational change and development. In W.A. Pasmore and R.W. Woodman (Eds.), Research in organizational change and development, Volume 8, Greenwich, CT: JAI Press (243295).

Enderle, G. (2001). Integrating the ethical dimension into the analytical framework for the reform of state-owned enterprises. Journal of Business Ethics, 30 (3), 261-276.

Fisher, J. (2003). Surface and deep approaches to business ethics. Leadership \& Organization Development Journal, 24 (2), 96101.

Freeman, E. (1984). Strategic management: A stakeholder approach. London: Pitman.

Fulmer, R.M. (2004). The challenge of ethical leadership. Organizational Dynamics, 33 (3), 307-317.

Garofalo, C. (2003). Toward a global ethic: Perspectives on values, training and moral agency. The International Journal of Public Sector Management, 16 (7), 490-501.

Gray, R.H. (1990). Business ethics and organisational change. Managerial Auditing Journal, 5 (2).

Haberberg, A., \& Rieple, A. (2001). The strategic management of organisations. Harlow: Prentice-Hall.

Harrison, J. (2001). Ethics for Australian Business. French's Forest: Prentice-Hall.

Hattingh, B. (2004). Ups and downs of mergers, acquisitions. Business Day, July 19, 1st edition.

IoD. (2002). Second King report on corporate governance for South Africa. Johannesburg: Institute of Directors (IoD).

Irvin, L. (2002). Ethics in organizations: A chaos perspective. Journal of Organizational Change Management, 15 (4), 359381.

Jennings, M.M., Smeltzer, L.R., \& Zener, M.F. (1993). The ethics of worker safety nets for corporate change. Journal of Business Ethics, 12, 459-468.

Johnson, R.A., Hoskisson, R.E., \& Hitt, M.A. (1990). Corporate restructuring: Implications for organization change and development. In R.W. Woodman and W.A. Pasmore (Eds.), Research in organizational change and development, vol. 4. Greenwich, CT: JAI Press.
Kavanagh, K. (Ed.), (2002). South African concise Oxford dictionary. Cape Town: Oxford University Press.

Kets de Vries, M.F.R. (1989) Leaders who self-destruct: The causes and cares. Organizational Dynamics, 17 (4), 4-18.

Lämsä, A. (1999). Organizational downsizing - an ethical versus managerial viewpoint. Leadership \& Organization Development Journal, 20 (7), 345-353.

Mariotti, J. (1998). 10 Steps to positive change. Industry Week, 247 (14), 82

Mayon-White, W.M. (1994). Focus on business change and ethics: The ethics of change management: Manipulation or Participation? Business Ethics, 3 (4), 196-200.

McGreevy, M. (2003). The changing nature of work. Industrial and Commercial Training, 35 (5), 191-195.

McKay, R.B. (2000). Applying ethical principles to the decision to build the Red Hill Creek Expressway. The International Journal of Public Sector Management, 13 (1), 58-67.

Miller, D. (2004). Building sustainable change capability. Industrial and Commercial Training, 36 (1), 9-12.

Miller, R.A. (1998). Lifesizing in an era of downsizing: An ethical quandary. Journal of Business Ethics, 17, 1693-1700.

Morrell, K.M., Loan-Clark, J., \& Wilkinson, A.J. (2004). Organisational change and turnover. Personnel Review, 33 (2), 161-173.

Mourier, P., \& Smith, M. (2001). Conquering organizational change: How to succeed where most companies fail. Atlanta: CEP Press.

Nielsen, W.R., Nykodym, N., \& Brown, D.J. (1991). Ethics and organizational change. Asia Pacific Journal of Human Resources, Autumn, 82-93.

Offerman, L.R., \& Gowing, M.K. (1990). Organizations of the future: Changes and challenges. American Psychologist, 45 (2), 95-108.

Panchal, S., \& Cartwright, S. (2001). Group differences postmerger stress. Journal of Managerial Psychology, 16 (6), 424433.

Pettijohn, L.S., Parker, S., Pettijohn, C.E., \& Kent, J.L. (2001) Performance appraisals: Usage, criteria and observations. Journal of Management Development, 20 (9), 754-771.

Rossouw, G.J. (2005). The philosophical premises of the second King report on corporate governance and the implications thereof. Paper presented at the $5^{\text {th }}$ Annual Conference of the Business Ethics Network of Africa, Kasane, Botswana, August 30 . September 1.

Rossouw, G.J., \& Van Vuuren, L.J. (2004). Business Ethics. Cape Town: Oxford University Press.

Shapiro, D.L,, \& Kirkman, B.L. (1999). Employees' reaction to the change to work teams: The influence of "anticipatory justice". Journal of Organizational Change Management, 12 (1), 51-66

Simmons, J. (2004). Managing in the post-managerialist era: Towards socially responsible corporate governance. Management Decision, 42 (3/4), 601-611.

Skarlicki, D.P., \& Folger, R. (1997). Retaliation in the workplace: The roles of distributive, procedural and interactional justice. Journal of Applied Psychology, 82 (3), 434-443.

Skrzycki, C. (1989). The drive to downsize. Washington Post, August 20, B1.

Smith, D.R. (1995). Change: Still an enigma to be faced. Hospital Material Management Quarterly, 16 (4), 76-82.

Smith, M.E. (2002). Success rates for different types of organizational change. Performance Improvement, 41 (1), 26-33.

Stephens, C.U., \& Cobb, A.T. (1999). A Habermasian approach to justice in organizational change: Synthesizing the technical and philosophical perspectives. Journal of Organizational Change Management, 12 (1), 21-34.

Svensson, G., \& Wood, G. (2005). Corporate ethics in TQM: Management versus employee expectations and perceptions. The TQM Magazine, 17 (2), 137-149.

Van Tonder, C.L. (2006). The application of Nonlinear Change Theory to the demise of Saambou Bank. SA Journal of Economic and Management Sciences, 9 (2), 149-174. 
Van Tonder, C.L. (2005a). Complex, chaotic and catastrophic: The advent of nonlinear change. Paper presented at the 5th International Conference on Knowledge, Culture and Change in Organisations, Rhodes, Greece, 19-22 July.

Van Tonder, C.L. (2005b)._The unacknowledged contribution of organisational change practice to organisational and employee wellness. Proceedings of the 2005 International Conference on the Changing World of Work, 8-9 March, Vanderbijl Park, South Africa, 102-115.

Van Tonder, C.L. (2004a). Organisational change: Theory and practice. Pretoria: Van Schaik.

Van Tonder, C.L. (2004b). The march of time and the "evolution" of change. SA Journal of Industrial Psychology, 30 (3), 41-52.

Van Tonder, C.L. (2004c). Organisations on the edge: Focusing on and exploring the nature of non-linear organisational change. Paper presented at the International Workshop on Complexity and Philosophy, Rio de Janeiro, November 2004.

Van Tonder, C.L., \& Van Vuuren, L.J. (2004). Recognising ethical nodes in organisational change: A conceptual framework.
Paper presented at the $4^{\text {th }}$ Annual Conference of the Business Ethics Network of Africa, Zanzibar, Tanzania, September 1-3.

Vinten, G. (2001). Corporate governance and the sons of Cadbury. Corporate Governance, 1 (4), 4-8.

Vinten, G. (1998). Putting ethics into quality. The TQM Magazine, 10 (2), 89-94.

Woodall, J. (1996). Managing culture change: Can it ever be ethical? Personnel Review, 26 (6), 26-40.

Worrall, L., \& Cooper, C.L. (1995). Executive stress in different industrial sectors, structures and sizes of business. Personnel Review, 24 (7), 3-12.

Worrall, L., Cooper, C.L., \& Campbell-Jamison, F. (2000). The impact of organizational change on the work experiences and perceptions of public sector managers. Personnel Review, 29 (5), 613-636.

Wooten, K.C., \& White, L.P. (1999). Linking OD's philosophy with justice theory: Postmodern implications. Journal of Organizational Change Management, 12 (1), 7-20. 